\title{
PERANAN SEKTOR PUBLIK LOKAL DALAM PERTUMBUHAN EKONOMI REGIONAL DI WILAYAH SURAKARTA $(1987-2000)^{1}$
}

\author{
Siti Aisyah Tri Rahayu \\ Universitas Sebelas Maret Surakarta
}

\begin{abstract}
This paper's aim is to explain the role of the local public sectors in regional economic growth in Ex Residency of Surakarta. The question we ask in this paper is whether local taxes and local expenditures affect regional economic growth in Ex Residency of Surakarta. This question is very important in two respect. First, It would be especially interesting to know whether local government taxes and/or expenditures have had an impact on regional economic growth. An alternative view argues againts any such impact. Second, as local autonomy will soon be granted, local government need to understand the mechanism by which local taxes and expenditures affect the regional economy.

The major finding in this paper area as follows. The role of local government in regional economic growth has been very significant. Local taxes and local revenues have a significant negative effect on local regional economic growth, while local government investment have a significant positive effect on regional economic growth. On the other hand, Local government consumption and labor force have no significant effect on regional economic growth.

One of the crusial policy implication of this paper is that we must enhance the role of local government, local autonomy having been recently introduced. More specifically, the central government should transfer more revenue sources to its lower level local government through. For example, revenue sharing of national taxes.
\end{abstract}

Keywords: local public sector - regional economic growth - regional economic gap.

\section{PENDAHULUAN}

Tidak dapat dipungkiri bahwa kehidupan selama ini sangat bergantung kepada jasa yang disediakan oleh pemerintah. Banyak pihak yang mendapatkan keuntungan dari aktivitas dan pengeluaran pemerintah. Sebagai contoh, pengeluaran tahunan pemerintah Amerika Serikat selama 20 tahun terakhir rata-rata mencapai 1/3 dari Gross Domestic Product (GDP) (Hyman, 1996).

Pasal 18 UUD 1945, dan UU Nomor 5 Tahun 1975 serta UU Otonomi Daerah Nomor 22 Tahun 1999, menjamin adanya desentralisasi - otonomi baik di daerah besar maupun daerah kecil (Kabupaten/kota dan Kabupaten). Undang-undang Nomor 5 tahun 1974 tentang Pokok-pokok Pemerintahan di Daerah telah meletakkan dasar sistem hubungan pusat-daerah yang dirangkum dalam tiga prinsip: desentralisasi, dekonsentrasi, tugas perbantuan. Akibat prinsip-prinsip ini, dikenal adanya daerah otonom dan wilayah administratif.

Salah satu indikator yang digunakan untuk mengukur keberhasilan pembangunan ekonomi suatu daerah adalah Produk Domestik Regional Bruto (PDRB), yang merupakan keseluruhan nilai tambah barang

\footnotetext{
1 Penelitian Dosen Muda dibiayai Proyek Pengkajian dan Penelitian IImu Pengetahuan Terapan dengan Surat Perjanjian Pelaksanaan Penelitian Nomor 031/P4T/DPPM/PDM/III/2003. Penelitian ini dilaksanakan pada tahun 2003 dengan Laporan Akhir sebanyak 49 halaman.
} 
dan jasa yang dihasilkan oleh berbagai sektor ekonomi di suatu daerah dalam periode tertentu, biasanya satu tahun.

Sementara itu dilihat dari peranan sektor publik lokal, proporsi penerimaan dan pengeluaran daerah tingkat I di seluruh Indonesia terhadap PDRB tanpa migas menunjukkan kecenderungan menurun dari tahun ke tahun. Dalam tahun anggaran 1993/1994 proporsi penerimaan dan pengeluaran daerah tingkat I terhadap PDRB tanpa migas masing-masing adalah 2,9 persen dan 2,7 persen menurun menjadi 2,4 persen dan 2,3 persen dalam tahun anggaran 1997/1998. Demikian pula dengan proporsi penerimaan dan pengeluaran daerah tingkat II seluruh Indonesia terhadap PDRB tanpa migas menurun menjadi 3,5 persen dan 3,3 persen dalam tahun anggaran 1993/1994 menjadi 3,4 persen dan 3,2 persen dalam tahun anggaran 1996/1997 (Nota Keuangan dan RAPBN tahun 1999/2000).

Menurunnya proporsi penerimaan dan pengeluaran pemerintah daerah terhadap PDRB tanpa migas menunjukkan semakin meningkatnya peranan sektor-sektor ekonomi di luar sektor pemerintah daerah (sektor publik lokal) dalam menunjang pembangunan ekonomi di daerah.

Selama ini realitas hubungan fiskal antara pusat-daerah ditandai dengan tingginya kontrol pusat terhadap proses pembangunan di daerah. Ini jelas terlihat dari rendahnya proporsi PAD (Pendapatan Asli Daerah) terhadap total pendapatan daerah dibandingkan dengan besarnya subsidi (grants) yang didrop dari pusat. Indikator desentralisasi fiskal adalah rasio antara PAD dengan total pendapatan daerah. Dalam kurun waktu 1984/85-1990/91, proporsi PAD terhadap total pendapatan daerah di 27 kabupaten/kota di Indonesia rata-rata hanya 15,4 persen dan berturut-turut meningkat menjadi 26,24 persen dan 36,17 persen dalam tahun anggaran 1993/1994 dan tahun anggaran 1997/1998. Semua kabupaten/kota kecuali DKI Jakarta, mempunyai PAD kurang dari 50 persen. Artinya lebih banyak subsidi dari pusat dibandingkan dengan PAD dalam pembiayaan pembangunan daerah. Bila diperinci, PAD hanya membiayai pengeluaran rutin daerah kurang dari 30 persen, bahkan untuk Dati II lebih buruk lagi, karena kurang dari 22 persen pengeluaran rutinnya dibiayai oleh PAD.

Ironisnya, meskipun titik berat otonomi daerah difokuskan pada Dati II, namun kenyataannya justru Dati II-lah yang paling tergantung pada sumbangan/bantuan pemerintah pusat. Sebagian besar Dati II di Indonesia, tepatnya 173 Dati II atau 59,25\% dari total Dati II Indonesia, memiliki angka prosentase PAD terhadap total belanja daerah kurang dari $15 \%$. Setidaknya ada lima hal menyebabkan rendahnya PAD, sehingga pada gilirannya menyebabkan tingginya ketergantungan terhadap subsidi dari pusat, yaitu: Pertama, kurang berperannya perusahaan daerah sebagai sumber pendapatan daerah. Kedua, tingginya derajat sentralisasi dalam bidang perpajakan. Semua pajak utama, yang paling produktif dan buoyant baik pajak langsung maupun pajak tak langsung, ditarik oleh pusat. Penyebab ketiga adalah kendati pajak daerah cukup beragam ternyata hanya sedikit yang bisa diandalkan sebagai sumber penerimaan. Kemudian faktor keempat adalah faktor yang bersifat politis. Banyak kekhawatiran apabila daerah mempunyai sumber keuangan yang tinggi akan mendorong terjadinya disintegrasi dan separatisme. Dan faktor terakhir penyebab ketergantungan tersebut adalah kelemahan dalam pemberian subsidi pemerintah pusat kepada pemerintah daerah. Karena selama ini pemberian subsidi dalam bentuk blok (block grants) yang lebih memberikan keleluasaan Pemda untuk mengelolanya ternyata jumlahnya lebih kecil daripada subsidi spesifik (specific grants) yang penggunaannya sudah ditentukan oleh pusat.

'Karesidenan Surakarta adalah satu wilayah bekas pembantu Gubernur yang cukup potensial, akan tetapi ada beberapa aspek yang masih harus dikaji berkaitan dengan kesiapannya dalam era otonomi daerah saat ini. Hasil penelitian yang dilakukan oleh penulis pada tahun 2002 mengenai "Analisis Potensi Keuangan Daerah Menuju Pelaksanaan Otonomi Daerah: Studi Kasus di Kabupaten/Kota se eks Karesidenan Surakarta" (Rahayu dkk., 2002), memperlihatkan hasil bahwa derajat desentralisasi fiskal kota/kabupaten se Eks Karesidenan Surakarta umumnya masih rendah. Temuan lainnya adalah bahwa posisi fiskal daerah kota/kabupaten se Eks Karesidenan Surakarta masih rendah kecuali kota Surakarta. Sementara itu, didapatkan bahwa tidak ada pengaruh tingkat perkembangan ekonomi dan kontribusi sumbangan atau bantuan terhadap derajat otonomi fiskal. Melihat permasalahan yang dihadapi oleh daerah saat ini dan di masa mendatang, terutama dalam hal ini, sebagai kelanjutan analisis terdahulu dan dalam rangka menyongsong dilaksanakannya otonomi daerah inilah penulis ingin melihat kemampuan dan peranan dari 
sektor publik lokal terhadap pertumbuhan ekonomi daerah di wilayah Surakarta atau yang dikenal dengan SUBOSUKOWONOSRATEN (Surakarta, Boyolali, Sukoharjo, Wonogiri, Sragen dan Klaten). Dengan melihat latar belakang permasalahan, tulisan ini bermaksud untuk membuktikan dan menjelaskan peran sektor publik lokal terhadap pertumbuhan ekonomi regional dalam mrangka menghadapi otonomi daerah di wilayah Surakarta.

\section{TINJAUAN PUSTAKA}

\subsection{Hasil Penelitian Sebelumnya}

Ada beberapa studi terdahulu yang meneliti mengenai peranan sektor publik lokal terhadap pertumbuhan ekonomi regional ini dan yang berkaitan dengan hal ini. Beberapa diantaranya adalah penelitian yang dilakukan oleh Kim (1997) atas masalah yang sama di negara Korea yang juga menerapkan otonomi daerah mulai tahun 1995. Hasil dari penelitian tersebut adalah bahwa peranan dari sektor publik lokal selama periode 1970-1991 mempunyai pengaruh yang signifikan terhadap pertumbuhan ekonomi di Korea (Kim, 1997:167). Diantaranya adalah bahwa pajak lokal (daerah) dan penerimaan non-pajak mempunyai pengaruh negatif yang signifikan terhadap pertumbuhan ekonomi, sementara investasi dan konsumsi pemerintah daerah mempunyai pengaruh positif yang kuat dan signifikan. Penemuan Kim lainnya adalah bahwa ternyata disparitas pendapatan antar daerah di Korea lebih disebabkan oleh sektor swasta daripada oleh sektor publik lokal.

Studi dari Helms (1985) dengan menggunakan panel data menemukan bahwa kenaikan dalam pajak lokal dan pajak negara bagian (state) secara signifikan memperlambat pertumbuhan ekonomi ketika penerimaannya digunakan untuk membiayai transfer. Akan tetapi, bagaimanapun ketika penerimaan digunakan untuk membiayai pemeliharaan dan pengembangan jasa-jasa publik, pajak lokal akan mempunyai pengaruh yang menguntungkan terhadap perekonomian regional (Helms, 1985:581).

Carlton (1983) dalam studinya mengenai pilihan tenaga kerja dan lokasi dari perusahaan baru, mendapatkan bahwa tidak ada hubungan antara pajak dan pertumbuhan. Sementara itu Sugiyanto dkk. (1995), meneliti pengaruh pajak terhadap pertumbuhan ekonomi di Indonesia, yang dilakukan dengan cara menurunkan model dengan memasukkan pajak sebagai salah satu variabel yang dipertimbangkan masyarakat untuk menentukan jumlah uang yang beredar. Hasil dari estimasi model yang dipakai ternyata pajak bersifat menghambat pertumbuhan ekonomi. Pajak berhubungan negatif terhadap pertumbuhan ekonomi selama periode pengamatan (1970-1994). Disebutkan bahwa kenaikan pajak yang dipungut oleh pemerintah akan diikuti oleh penurunan kegiatan ekonomi masyarakat (Sugiyanto, 1995:45). Kenyataan ini bertentangan dengan hasil studi dari Patnasari (1999) yang mendapatkan bahwa penerimaan perpajakan berpengaruh positif dan signifikan terhadap pertumbuhan ekonomi baik dalam jangka pendek maupun dalam jangka panjang. Demikian pula untuk penerimaan migasnya berpengaruh secara positif dalam jangka pendek terhadap pertumbuhan ekonomi. Sementara pengeluaran pemerintah mempunyai pengaruh yang negatif dalam jangka pendek, akan tetapi berdampak positif dalam jangka panjang. Dengan demikian kesimpulan secara umum dari studi yang dilakukan Patnasari adalah bahwa kebijakan fiskal yang dilakukan pemerintah melalui pengeluaran pemerintah selama ini mempunyai pengaruh yang penting dalam memacu pertumbuhan ekonomi di Indonesia selama periode diamati (1969-1997).

Sementara itu Grosmann dkk (Grossmann, 1996), dalam studinya mengenai inefisiensi sektor publik di kota-kota besar di US, dengan menggunakan analisa teknik possibility frontier berkesimpulan bahwa ternyata terjadi inefisiensi dalam aktivitas porduksi sektor publik di kota-kota besar di US.

Belli dalam artikelnya dalam Kim (Kim, 1997) menyimpulkan bahwa intervensi pemerintah (sektor publik) diperlukan sekalipun tidak terjadi kegagalan pasar (market failure). Intervensi tersebut misalnya dalam hal pengurangan tingkat kemiskinan dan dalam kasus barang merit. Belli memberi penekanan bahwa intervensi pemerintah, dalam setiap kasus, harus memperhatikan identifikasi dari kegagalan pasar tertentu apa yang mencegah sektor swasta memproduksi barang-barang sosial secara optimal, kedua, harus diseleksi bahwa intervensi tersebut mempunyai efek meningkatkan kemakmuran , dan ketiga, harus diperlihatkan juga bahwa masyarakat akan menjadi tidak lebih baik dengan adanya keterlibatan pemerintah itu. Dari sini harus 
dapat diperhitungkan dan dipastikan bahwa keuntungan yang diperoleh masih lebih besar daripada biaya yang dikeluarkan untuk intervensi.

Dalam menguraikan penyebab dari ketidakefisienan sektor publik, Bartel and Harrison (1998) dalam studinya memperbandingkan performance antara sektor swasta dan sektor publik yang mengambil contoh kasus di Indonesia dari tahun 1981-1995 menemukan bahwa penyebab inefisiensi sektor publik itu adalah :(1) karena masalah monitoring; (2) Perusahaan tidak efisien karena lingkungan di mana mereka beroperasi, diukur dengan kendala anggaran yang lemah/terbatas atau adanya hambatan untuk berkompetisi. Hasil empiris dari studi tersebut adalah bahwa perusahaan publik tidak efisien karena tingkat produktivitas yang rendah dibandingkan dengan perusahaan swasta.

Hasil penelitian Bartel dan Harrison tersebut sejalan dengan hasil studi Estache dan Rossi (Estache and Rossi 1999:23), ketika membandingkan performance perusahaan air publik dan private di wilayah Asia dan Pasifik. Hasil studi tersebut menemukan bahwa ternyata sektor swastalah yang lebih efisien dibandingkan sektor publik

Rama (Rama:55.) menyarankan perlunya penurunan peranan sektor publik terutama di beberapa negara berkembang, sebagaimana juga diberlakukannya liberalisasi perdagangan dan keuangan dua dekade yang lalu. Hal ini sama dengan apa yang dikemukakan oleh Kompas (Kompas,2000: 6), yaitu bahwa hasil studi mengenai hubungan antara government size dan growth di Indonesia dan di Australia menunjukkan bahwa pengurangan pengeluaran pemerintah - terutama untuk sektor publik yang tidak mempunyai pengaruh yang nyata - akan menaikkan tingkat pertumbuhan.

Dilain pihak penelitian Ram (Ram,1986:202) mengenai hubungan antara besarnya pengeluaran pemerintah dan pertumbuhan ekonomi terhadap 115 negara maju dan berkembang mendapatkan bahwa meskipun sulit untuk disimpulkan bahwa pengeluaran pemerintah mempunyai efek positif terhadap kondisi perekonomian dan pertumbuhan ekonomi.

\subsection{Definisi Sektor Publik}

Dengan demikian sebelumnya kita sepakati bahwa yang akan dibahas dalam tulisan ini adalah berhubungan dengan ekonomi kebijakan anggaran (economics of budget policy). Batasan dari "sektor publik" yang digunakan dalam penelitian ini merujuk hanya pada kebijakan anggaran sektor publik yang meliputi penerimaan dan pengeluaran pemerintah dalam anggaran belanjanya.

\subsection{Fungsi Utama Sektor Publik}

Menurut Musgrave (Musgrave and Musgrave, 1980:6) meskipun pemerintah sudah menerapkan pajak tertentu dan mengelola pengeluarannya untuk mempengaruhi sistem perekonomian, masih diperlukan kebijakan-kebijakan lain guna mencapai tujuan yang lebih jauh lagi. Kebijakan-kebijakan pemerintan tersebut dapat dibagi ke dalam tiga golongan besar, yaitu:

\section{Fungsi Alokasi}

2. Fungsi Distribusi

3. Fungsi Stabilisasi

3) Pemerintah Daerah (Lokal)

Dari perspektif ekonomi publik, pembicaraan tentang pemerintah lokal akan terkait erat dengan dua pertanyaan penting, yakni : (1) seberapa besar ukuran pemerintah lokal yang seharusnya, dan (2) apa untungnya jika pengambilan keputusan dibuat pada tingkat lokal (Cullis and Jones, 1992 dan Fisher, 1996).

\subsection{Ukuran Pemerintah Daerah}

Pertanyaan tentang ukuran pemerintah daerah (lokal) terkait dengan efisiensi penyediaan barang publik. Sebab dalam penyediaan barang publik yang perlu dipertimbangkan tidak hanya barang apa yang diperlukan masyarakat melainkan juga masalah eksternalitas yang mungkin timbul, skala ekonomi dalam memproduksi barang publik tersebut dan kemampuan sumber pembiayaan. Maka adalah penting membahas tentang ukuran optimal suatu pemerintah daerah. Makna optimal haruslah makna efisiensi dan ukuran yang 
terkait dengan jumlah penduduk dan total pengeluaran untuk barang publik lokal (Cullis and Jones, 1992: 295323). Di samping itu Fisher menyatakan bahwa selain hipotesa Tiebout terdapat beberapa faktor yang harus dipertimbangkan dalam menentukan ukuran optimal suatu daerah. Faktor-faktor itu antara lain masalah eksternalitas antara wilayah, skala ekonomi dan persoalan sumber pembiayaan (Fisher, 1996: 129).

(1) Theory of The Club

Dalam teori ini dikaitkan antara marginal benefit yang diukur dari adanya penghematan biaya untuk penyediaan barang publik karena adanya pertambahan jumlah penduduk dan marginal cost yang diukur karena adanya kesimpangsiuran yang muncul dengan bertambahnya jumlah penduduk. Biaya dan manfaat ini selanjutnya dihubungkan dengan permintaan masyarakat atas barang publik dan biaya penyediaannya. Ukuran optimal pemerintah daerah akan dicapai manakala kedua keseimbangan ini tercapai.

Teori ini mengandung beberapa kelemahan antara lain : (1) marginal cost dari produksi output bersifat increasing, (2) tidak semua manfaat barang publik yang tersedia dapat dinimmati oleh yang menyediakan, (3) individu dalam masyarakat memiliki selera dan pendapatan yang sama, (4) ukuran optimal pemerintah lokal tergantung pada barang publik yang dibicarakan

(2) Hipotesis Tiebout

Hipotesis Tiebout terkait dengan masalah bagaimana individu memilih klub (dalam hal ini memilih otoritas lokal dimana dia hendak bermukim). Tiebout menyatakan bahwa individu akan menunjukkan perspektifnya terhadap pemerintah lokal dengan cara berpindah ke wilayah yang dapat mencerminkan selera terbaik mereka dan menawarkan benefit-tax yang paling dikehendaki. Inilah yang biasa dikenal dengan istilah voting with their feet (Cullis and Jones, 1992: 300-301).

Tiebout hipotesis ini sejalan dengan teorema desentralisasi, bahwa dengan hipotesis ini akan meningkatkan kesejahteraan (welfare) dari adanya desentralisasi. Perpindahan penduduk sesuai dengan preferensinya dengan pertimbangan batasan yang dimiliki âkan menggeser trade-off antara otonomi lokal dengan standar nasional ke arah otonomi lokal sebab adanya peningkatan homogenitas preferensi antara wilayah-wilayah.

(3) Variabel Lain Penentu Ukuran Pemerintah Daerah

Mengatasi kelemahan kedua pendekatan di atas, Fisher menyatakan ada berbagai faktor yang harus dipertimbangkan dalam menentukan ukuran pemerintah daerah yang optimal. Faktor-faktor ekonomi yang harus menjadi pertimbangan dalam penentuan ukuran optimal dari suatu pemerintah daerah antara lain (Fisher, 1996 : 129-140):

a) adanya variasi dalam permintaan

b) adanya eksternalitas spasial

c) adanya batasan skala ekonomis

d) ketersediaan biaya administrasi dalam penyediaan barang publik

Di samping keempat faktor di atas, dalam kehidupan nyata terdapat beberapa hal yang harus menjadi pertimbangan antara lain adalah: (1) prinsip korespondensi, (2) pertentangan antara preferensi dan spillover, (3) pengelompokkan barang publik dan pengambilan keputusan biaya, (4) penyediaan jasa melalui sistem kontrak.

Dalam kaitannya dengan pemerintah lokal, Sumodiningrat (1999) menyatakan bahwa APBD adalah alat untuk menjalankan otonomi daerah yang nyata dan bertanggung jawab dan merupakan rencana operasional pemerintah daerah yang menggambarkan pengeluaran untuk kegiatan dan proyek daerah dalam satu anggaran tertentu dan sumber penerimaan daerah untuk mencukupi pengeluaran tersebut.

\subsection{Kerangka Penelitian}

Dalam penelitian ini, analisis mengenai peranan sektor publik local terhadap pertumbuhan ekonomi regional, akan dilakukan dengan mengestimasi factor-faktor yang termasuk dalam sector pubik diantaranya pengeluaran pemerintah daerah yang meliputi konsumsi dan investasi pemerintah daerah, , penerimaan pemerintah daerah dari pajak, laju angkatan kerja, dalam mempengaruhi pertumbuhan ekonomi regional di wilayah Surakarta selama tahun 1987-2000 dalam persamaan regresi dengan model panel data dari 7 Kabupaten/kota di Eks Karesidenan Surakarta. Secara ringkas diskemakan sebagai berikut: 


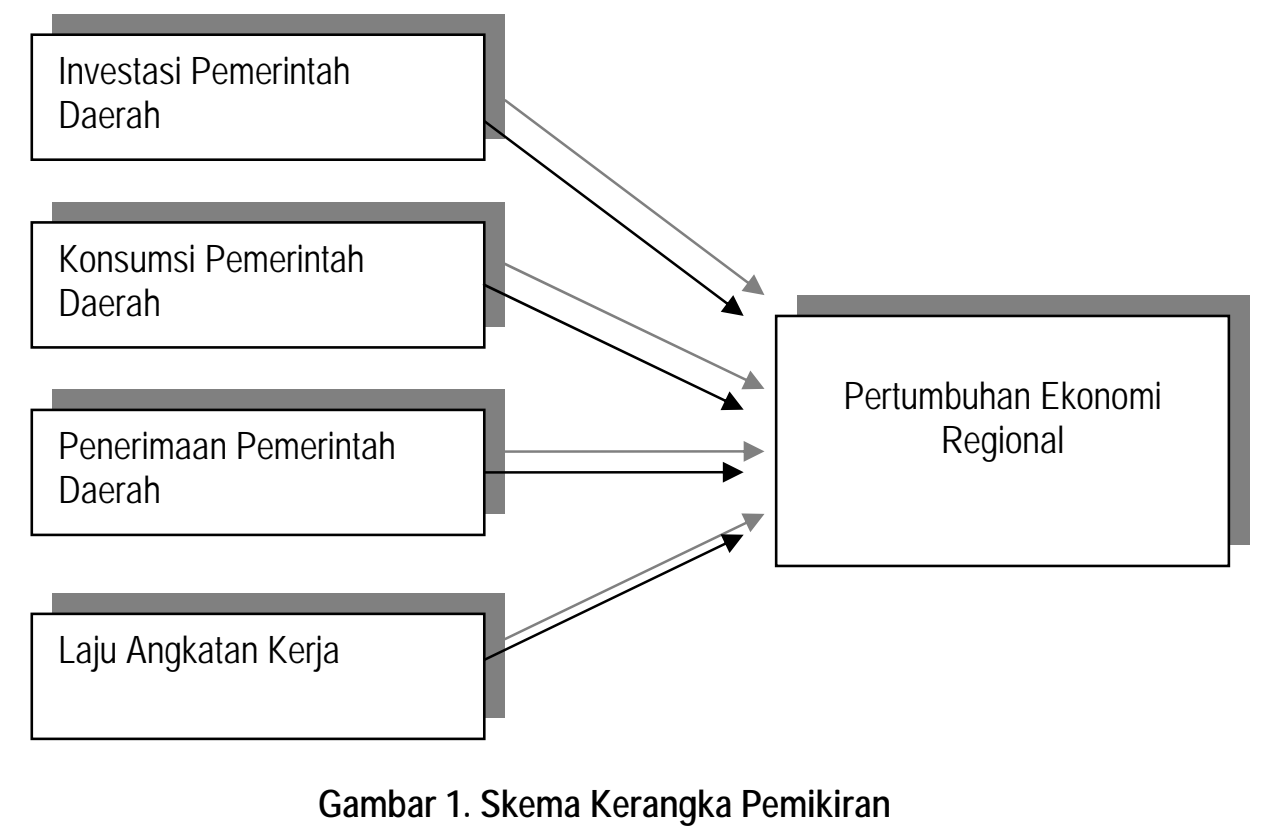

\subsection{Hipotesis}

Beberapa hipotesis yang akan diuji dalam penelitian ini antaralain :

1. Investasi pemerintah daerah berpengaruh positif terhadap pertumbuhan ekonomi regional

2. Laju pertumbuhan angkatan kerja berpengaruh positif terhadap pertumbuhan ekonomi regional

3. Pengeluaran (konsumsi) pemerintah daerah berpengaruh positif terhadap pertumbuhan ekonomi regional

4. Penerimaan penerimaan pemerintah berpengaruh negatif terhadap pertumbuhan ekonomi regional.

\section{METODA PENELITIAN}

\subsection{Daerah Penelitian}

Penelitian mengenai analisis peranan sektor publik lokal dalam pertumbuhan ekonomi regional di Wilayah Surakarta ini mengambit lokasi di kabupaten-kabupaten SUBOSUKOWONOSRATEN (Surakarta, Boyolali, Sukoharjo, Wonogiri, Sragen dan Klaten).

\subsection{Jenis data dan sumber pengumpulannya}

Penelitian ini menggunakan data sekunder yang diperoleh dari studi kepustakaan, seperti: Nota Keuangan dan RAPBN RI, RAPBD, Statistik Keuangan Daerah Tingkat II, SUSENAS, dan berbagai publikasi yang dikeluarkan oleh instansi-instansi Pemerintah Daerah Tingkat II di wilayah Surakarta, antara lain Kantor Statistik Kabupaten-kabupaten yang terdapat di wilayah Surakarta, Dipenda Kabupaten dan instansi-instansi yang terkait. Periode data yang digunakan adalah data periode 19872000.

Karena keseluruhan data yang digunakan dalam studi ini diperoleh dari data sekunder dari berbagai publikasi, yang oleh karenanya mengandung beberapa kelemahan, sehingga perlu diadakan penyesuaian terhadap data-data tersebut yaitu:

a. Data yang disusun menurut tahun anggaran atau fiskal harus diubah dulu menjadi tahun takwim. Caranya adalah dengan menggunakan rumus interpolasi (Insukindro,1993:142) sebagai berikut: $\mathrm{Q}_{\mathrm{kt}}=1 / 4 \mathrm{Qt}\left[1-(\mathrm{k}-2,5)(1-\mathrm{B})^{1 / 4}\right]$

Dimana : Qkt = data kuartalan ke $\mathrm{k}$ tahun $\mathrm{t}$

$\mathrm{Yt}=$ data tahun $\mathrm{t}$

$\mathrm{B}=$ Operasi kelambanan (backward lag operator)

Selanjutnya dari rumus tersebut diatas dijabarkan untuk menghitung data kuartalan masingmasing tahun sebagai berikut(Insukindro,1993:142): 
$\mathrm{Q}_{1 \mathrm{t}}=1 / 4\left[\mathrm{Y}_{\mathrm{t}}-4,5 / 12\left(\mathrm{Y}_{\mathrm{t}}-\mathrm{Y}_{\mathrm{t}-1}\right)\right]$

$\mathrm{Q}_{2 \mathrm{t}}=1 / 4\left[\mathrm{Y}_{\mathrm{t}}-1,5 / 12\left(\mathrm{Y}_{\mathrm{t}}-\mathrm{Y}_{\mathrm{t}-1}\right)\right]$

$\mathrm{Q}_{3 \mathrm{t}}=1 / 4\left[\mathrm{Y}_{\mathrm{t}}+1,5 / 12\left(\mathrm{Y}_{\mathrm{t}}-\mathrm{Y}_{\mathrm{t}-1}\right)\right]$

$\mathrm{Q}_{4 \mathrm{t}}=1 / 4\left[\mathrm{Y}_{\mathrm{t}}+4,5 / 12\left(\mathrm{Y}_{\mathrm{t}}-\mathrm{Y}_{\mathrm{t}-1}\right)\right]$

Dimana $k=1,2,3,4$; Qkt adalah data kuartalan ke-k tahun t; Yt adalah data yang diinterpolasi pada tahun $t$ dan Yt-1 adalah data tahun t-1 (kelambanan).

Data yang menggunakan satuan mata uang dollar US harus dikonversikan menjadi rupiah atau sebaliknya

b. Untuk data produk domestik bruto harus menggeser tahun dasar yang dipakai menjadi berdasarkan harga konstan tahun 1983.

\subsection{Operasional Variabel}

\subsubsection{Produk Domestik Regional Bruto: $Y$}

Laju pertumbuhan Produk Domestik Regional Bruto (pertumbuhan ekonomi regional) dengan cara : (Suseno, 1990:36)

$$
Y_{t}=\frac{Y_{t}-Y_{t-1}}{Y_{t-1}} \times 100 \%
$$

Di mana :

$Y_{t}=$ laju pertumbuhan ekonomi regional (dalam persentase)

$t \quad=$ tahun tertentu

$t-1=$ tahun sebelumnya

$Y=$ Produk Domestik Regional Bruto (dalam trilyun rupiah)

\subsubsection{Laju Pertumbuhan Tenaga Kerja : $\dot{L}$}

Definisi Angkatan kerja disini diambil dari definisi yang dipakai oleh BPS, yaitu mencakup orang yang bekerja dengan maksud untuk memperoleh penghasilan atau keuntungan, punya pekerjaan tetapi sedang tidak bekerja dan yang sedang mencari pekerjaan.

Data Laju pertumbuhan angkatan kerja $(L)$ ini diperoleh dari jumlah total angkatan kerja di tiap-tiap kabupaten/kota di wilayah Surakarta. Data $L$ ini kami peroleh dari Angkatan kerja yang diterbitkan oleh BPS. $L$ diukur dengan:

$$
\begin{aligned}
& \dot{L}=\left(L_{t}-L_{t-1}\right) / L_{t-1} \\
& \text { Di mana : }
\end{aligned}
$$

$$
\begin{array}{ll}
\dot{L} & =\text { laju pertumbuhan angkatan kerja (dalam persentase) } \\
t & =\text { tahun tertentu } \\
t-1 & =\text { tahun sebelumnya } \\
L & =\text { Jumlah angkatan kerja (dalam satuan jiwa) }
\end{array}
$$

\subsubsection{Investasi Pemerintah Daerah : $I_{g}$}

Data investasi pemerintah daerah ini diperoleh dari besarnya pengeluaran pembangunan dalam Anggaran Pendapatan dan Belanja Daerah (APBD) tiap-tiap kabupaten/kota di Indonesia. Pengeluaran pembangunan ini meliputi pengeluaran untuk industri, pengeluaran untuk pembangunan daerah dan perekonomian. Pengeluaran untuk industri dan ekonomi termasuk juga didalamnya pertanian dan perikanan, kehutanan dan pengeluaran ekonomi regional. Pengeluaran pembangunan regional meliputi pembangunan perkotaan, konstruksi jalan, dan bermacam-macam pengeluaran pembangunan regional lainnya. Variabel $I_{g} / Y$ ini diukur dengan rumus:

$$
\lg t Y=\lg t / Y_{t-1}
$$

Di mana :

$I_{g} \quad=$ Pengeluaran pembangunan pemerintah derah (dalam trilyun rupiah)

$t \quad=$ tahun tertentu

$t-1=$ tahun sebelumnya

$Y \quad=$ Produk Domestik Regional Bruto (dalam trilyun rupiah) 


\subsubsection{Konsumsi Pemerintah Daerah : $G$}

Konsumsi pemerintah daerah ini diukur dengan menjumlahkan pengeluaran unutk membiayai administrasi umum, kesejahteraan sosial dan pengeluaran lainnya termasuk pertahanan dan pengeluaran untuk pendidikan. Data konsumsi pemerintah daerah ini diambil dari pengeluaran rutin pemerintah daerah dalam APBD yang diperoleh dari Statistik Keuangan Pemerintah Daerah Tingkat I Seluruh Indonesia yang diterbitkan oleh Badan Pusat Statistik.

Variabel ini ditimbang dengan pertumbuhan pemerintah daerah yang merupakan pembagian dari konsumsi pemerintah dalam PDRB, $\left[G / Y_{t}\right]$, dikalikan dengan tingkat pertumbuhan konsumsi pemerintah daerah. Pertumbuhan konsumsi pemerintah daerah di hitung dengan rumus:

$$
G=\left(G_{t}-G_{t-1}\right) / G_{t-1}
$$

Di mana :

$G=$ Pengeluaran rutin pemerintah daerah (dalam trilyun rupiah)

$t \quad=$ tahun tertentu

$t-1=$ tahun sebelumnya

\subsubsection{Penerimaan Pemerintah (Revenue Effort) : $R / Y$}

Revenue effort ini adalah rasio dari jumlah penerimaan pemerintah dari pajak lokal dan penerimaan bukan pajak terhadap PDRB. Data ini diperoleh dari penerimaan pemerintah daerah Kabupaten/kota dalam APBD dalam Statistik Keuangan Pemerintah Dati I yang diterbitkan oleh BPS dari berbagai edisi. Rasio penerimaan pemerintah dari pajak lokal dihitung dari Produk Domestik Regional Bruto dibagi dengan penerimaan pemerintah ari pajak lokal, yang kesemuanya dalam satuan rupiah.

\section{Kerangka Analisis}

Dalam penelitian ini, alat analisis yang akan digunakan âdalah model dikembangkan dari model pertumbuhan ekonomi makro (macroeconomic growth model) dari Skinner (1987) yang digunakan oleh Kim (1997) untuk meneliti tentang peranan sektor publik lokal terhadap pertumbuhan ekonomi regional di Korea dari tahun 1970-1991, dengan menggunakan panel data cross section dan time series dari sebelas wilayah di Korea.

Sementara penelitian ini mengaplikasikan model Kim tadi untuk meneliti peranan sektor publik lokal terhadap pertumbuhan regional di wilayah Surakarta. Data yang digunakan adalah juga panel data cross section dan time series dari beberapa kabupaten/kota di wilayah Surakarta dari tahun 1987-2000. Spesifikasi model yang digunakan dalam penelitian ini adalah sebagai berikut:

$$
\dot{Y}=\beta_{0}+{ }_{l} \dot{L}+\gamma_{x}\left[\frac{I_{g}}{Y}\right]+\gamma_{g}\left[\frac{G}{Y}\right] \dot{G}+\varphi\left[\frac{R}{Y}\right]+\mu_{i}
$$

Dimana :

$\dot{Y} \quad=$ Laju Pertumbuhan Ekonomi regional (dalam persentase)

$\underline{I_{q}} / Y=$ Rasio Investasi pemerintah daerah dengan PDRB (dalam rasio)

$\dot{L} \quad=$ Laju angkatan kerja (dalam persentase)

$G / Y=$ Rasio Pengeluaran/konsumsi pemerintah daerah (dalam rasio)

$R / Y=$ Rasio Penerimaan pemerintah dari pajak dan bukan pajak dengan PDRB (dalam rasio)

$\mu_{i}=$ variabel gangguan (disturbance error terms)

$\beta_{0}$ disini mengukur perubahan produktivitas yang tidak bias, $\beta_{k}$ mengukur rata-rata gross marginal factor product of capital dan $\beta$ mengukur elastisitas output secara keseluruhan terhadap tenaga kerja, dan $\gamma_{x}$ dan $\gamma_{g}$ dipakai sesuai dengan definisi secara umum.

\section{MODEL REGRESI DENGAN PANEL DATA}

Model yang dipakai dalam penelitian ini adalah panel data yang merupakan gabungan antara observasi lintas sektoral dan runtun waktu. Estimasi panel data akan meningkatkan derajat kebebasan, mengurangi kolinearitas antara variabel penjelas dan memperbaiki efisiensi estimasi. Verbeek (2000:310) 
mengemukakan bahwa keuntungan regresi dengan data panel adalah kemampuann regresi data panel dalam mengidentifikasi parameter-parameter regresi secara pasti tanpa membutuhkan asumsi restriksi atau kendala. Menurut Baltagi (1995), keunggulan penggunaan data panel dibanding data runtun waktu dan data lintas sektoral adalah: 1) Estimasi data panel dapat menunjukkan adanya heterogenitas dalam tiap unit; 2) Dengan data panel, data lebih informatif, mengurangi kolinieritas antara variabel, meningkatkan erajat kebebasan dan lebih efisien; 3) data panel cocok untuk menggambarkan adanya dinamika perubahan; 4) Data panel dapat lebih mampu mendeteksi dan mengukur dampak; 5) Data panel bisa digunakan untuk studi dengan model yang lebih lengkap; 6) Data panel dapat meminimumkan bias yang mungkin dihasilkan dalam agregasi.

Menurut Pindyck dan Rubinfeld (1998) terdapat 3 (tiga) prosedur estimasi data panel: 1) Regresi penggabungan semua data; 2) regresi dengan variabel dami untuk mengetahui perubahan intersep runtun waktu dan lintas sektor; 3) error component model.

Estimasi model regresi penggabungan semua data untuk intersep dan koefisien slope konstan setiap waktu dan unit biasa disebut juga dengan estimasi regresi data panel dengan metode Pooled Least Square, mempunyai bentuk spesifikasi sebagai berikut:

$$
Y_{i t}=\beta_{1}+\beta_{2} X_{2 i t}+\beta_{3} X_{3 i t}+\mu_{i t}
$$

Jika model regresi diasumsikan mempunyai koefisien slope konstan tetapi intersep bervariasi tiap unit maka digunakan variabel dami waktu dan unit. Misal:

$$
Y_{i t}=\beta_{1 i}+\beta_{2} X_{2 i t}+\beta_{3} X_{3 i t}+\mu_{i t}
$$

Model (2) ini dikenal dengan Fixed Effect Model (FEM). Intersep meskipun bervariasi tiap unit tapi tidak berbeda dalam tiap waktu (time invariant).

Variabel dami digunakan untuk mengetahui besarnya perbedaan koefisien tiap unit (differential intercept dummies) dan model dapat dituliskan sebagai berikut:

$$
Y_{i t}=\alpha_{1}+\alpha_{2} D_{2 i}+\alpha_{3} D_{3 i}+\alpha_{4} D_{4 i}+\beta_{2} X_{2 i t}+\beta_{3} X_{3 i t}+\mu_{i t}
$$

Model (2) ini dikenal juga sebagai Covariance Model.

Selanjutnya, model estimasi regresi data panel yang ketiga adalah error component model atau disebut juga Random Effect Model (REM). Model REM ini melibatkan korelasi antar error term karena berubahnya waktu maupun karena berbedanya unit observasi. Model dasarnya dapat diformulasikan sebagai berikut:

$$
Y_{i t}=\beta_{1 t}+\beta_{2} X_{2 i t}+\beta_{3} X_{3 i t}+\mu_{i t}
$$

untuk melihat model mana yang paling sesuai dipakai dalam penelitian ini, penulis akan melakukan uji Restricted $F$ test untuk menguji apakah model (1) yang disebut juga dengan restricted model ataukah model (2) unretristed model yang akan dipakai. Formulasi Restricted $F$ test adalah sebagai berikut:

$$
F=\frac{\left(R_{U R}^{2}-R_{R}^{2}\right) / m}{\left(1-R_{U R}^{2}\right) / n-k}
$$

Di mana:

$R_{U R}^{2}=$ Koefisien determinasi dari model regresi unrestricted

$R_{R}^{2}=$ Koefisien determinasi dari model regresi restricted

$m$ = jumlah koefisien pada model regresi restricted

$n=$ jumlah seluruh observasi

$k=$ jumlah koefisien pada model regresi unrestricted

Keseluruhan model dalam studi ini diestimasi dengan menggunakan paket program Eviews 3.0. model yang dipakai dalam analisis ini adalah fixed effect model. Selanjutnya model diestimasi dengan metode Generalized Least Square. Dan terakhir adalah interpretasi hasil estimasi model yang digunakan dalam analisis ini.

Model estimasi regresi data panel ketiga yaitu Random Effect Model tidak digunakan oleh penulis dengan beberapa alasan. Pertama, tidak semua persamaan bisa diestimasi dengan random effect, hal ini 
disebabkan karena untuk mengolah model dengan metode generalized linear regression model dalam random effect model salah satu persyaratan yang harus dipenuhi adalah jumlah unit cross section (n) harus lebih besar dari jumlah parameter yang akan diestimasi/explanatory variables (K) (Kmenta, 1971: 500). Sedangkan untuk model regresi data panel yang dipakai penulis disini jumlah observasi $(n)$ masih lebih besar dari jumlah variabel penjelas $(\mathrm{K})$. penulis lebih cenderung untuk menggunakan estimasi dengan fixed effect model untuk semua persamaan. Disamping itu pertimbangan lainnya adalah karena untuk konsistensi analisis dan perbandingan antar semua persamaan sebaiknya menggunakan satu pendekatan yang sama untuk semua model. Dalam hal ini model yang bisa dipakai untuk semua persamaan adalah fixed effect model. Alasan lain digunakannya fixed effect model adalah karena, kesimpulan (inferensi) yang akan diambil dari model yang akan diteliti oleh peneliti disini hanya akan mempertimbangkan efeknnya pada sampel yang ada dan bukan pada populasi. Hal dimana berlainan dengan tujuan dipakainya random effect model, yaitu untuk melihat efeknya pada populasi dalam mengambil kesimpulan (Hsiao, 1990:41-42).

\section{ANALISIS HASIL ESTIMASI DAN PEMBAHASAN}

Keseluruhan model dalam studi ini diestimasi dengan menggunakan paket program Eviews 3.0. dengan menggunakan model panel data yaitu fixed effect model dengan spesifikasi model sebagai berikut:

$$
\dot{Y}=\beta_{0}+{ }_{l} \dot{L}+\gamma_{x}\left[\frac{I_{g}}{Y}\right]+\gamma_{g}\left[\frac{G}{Y}\right] \dot{G}+\varphi\left[\frac{R}{Y}\right]+\mu_{i}
$$

\section{1. Hasil Uji model}

Hasil perhitungan uji Restricted $F$ test adalah sebagai berikut:

$$
\begin{aligned}
& F=\frac{(0.922460-0.876408) / 5}{(1-0.876408) / 87}=\frac{0.00921}{0.001421} \\
& =6.483468
\end{aligned}
$$

Jika dibandingkan antara F-hitung dengan F- tabel (5 numerator dan 87 denumerator) maka dapat disimpulkan bahwa model yang diolah dengan Fixed Effect Model adalah model yang lebih baik.

\section{2. Hasil Estimasi Regresi Data Panel dengan Fixed Effect Model}

Tabel 1. Hasil Estimasi Regresi Data Panel dengan Fixed Efffect Model

\begin{tabular}{lcccc}
\hline \multicolumn{1}{c}{ Variable } & Coefficient & Std. Error & t-Statistic & Prob. \\
\hline R? & -0.002511 & 0.001074 & -2.338017 & 0.0214 \\
IG? & 0.002670 & 0.001271 & 2.100969 & 0.0381 \\
G? & 0.000567 & 0.000825 & 0.687755 & 0.4932 \\
L? & -0.050676 & 0.080136 & -0.632372 & 0.5286 \\
Fixed Effects & & & & \\
-SURAKARTA--C & 0.086121 & & & \\
-KLATEN--C & 0.150618 & & & \\
-KRANYAR--C & 0.106389 & & & \\
-BOYOLALI--C & 0.095097 & & & \\
-SRAGEN--C & 0.032288 & & & \\
-SUKOHARJO--C & -0.048468 & & & \\
-WONOGIRI--C & 0.153748 & & & \\
R-Squared & 0.876408 & Mean dependent var & 0.063365 \\
\hline
\end{tabular}

Dengan melihat hasil analisis print out komputer pada tabel 1 diatas, maka representasi dari hasil estimasi regresi adalah sebagai berikut: 
Surakarta:

$\dot{Y}=0,086121-0,002511 R / Y+0,002670 I_{g} / Y+0,000567\left(\frac{G}{Y}\right) \dot{G}-0,050676 \dot{L}$

Klaten:

$\dot{Y}=0,086121-0,002511 R / Y+0,002670 I_{g} / Y+0,000567\left(\frac{G}{Y}\right) \dot{G}-0,050676 \dot{L}$

Karanganyar:

$\dot{Y}=0,106389-0,002511 R / Y+0,002670 I_{g} / Y+0,000567\left(\frac{G}{Y}\right) \dot{G}-0,050676 \dot{L}$

Boyolali:

$$
\dot{Y}=0,095097-0,002511 R / Y+0,002670 I_{g} / Y+0,000567\left(\frac{G}{Y}\right) \dot{G}-0,050676 \dot{L}
$$

Sragen:

$\dot{Y}=0,003229-0,002511 R / Y+0,002670 I_{g} / Y+0,000567\left(\frac{G}{Y}\right) \dot{G}-0,050676 \dot{L}$

Sukoharjo:

$$
\dot{Y}=0,048468-0,002511 R / Y+0,002670 I_{g} / Y+0,000567\left(\frac{G}{Y}\right) \dot{G}-0,050676 \dot{L}
$$

Wonogiri:

$$
\dot{Y}=0,153748-0,002511 R / Y+0,002670 I_{g} / Y+0,000567\left(\frac{G}{Y}\right) \dot{G}-0,050676 \dot{L}
$$

Dalam bagian ini juga akan dibahas mengenai hasil empiris dari fixed effect model dari seluruh persamaan yang diestimasi. Dari hasil olah data kita memperoleh hasil bahwa koefisien dari Investasi pemerintah daerah $(I g / Y)$ menunjukkan kontribusi positif yang signifikan secara statistik dan mengestimasi multiplier dari investasi pemerintah lokal, yang mengimplikasikan bahwa setiap kenaikan $1 \%$ dalam $\mathrm{Ig} / Y$ menaikkan PDRB dengan 0,3\%. Jika rata-rata sampel dari Ig/ $Y$ adalah $14,62 \%$, maka kontribusi dari investasi pemerintah daerah terhadap pertumbuhan ekonomi regional adalah sebesar 0,002 × 14,62\%, memberikan 3,9\% terhadap kenaikan dalam PDRB.

Di sisi lain, Koefisien dari penerimaan pemerintah daerah dari pajak dan bukan pajak memberikan efek negatif yang signifikan terhadap pertumbuhan ekonomi regional sebesar $0,2 \%$. Jika koefisien ini dikalikan dengan rata-rata sampel dari variabel $\mathrm{R} / \mathrm{Y}$ sebesar 30,11, maka kontribusi penerimaan pemerintah daerah terhadap pertumbuhan ekonomi regional adalah $-0,002 \times 30,11 \%$, mengakibatkan penurunan sebesar $7,6 \%$ terhadap PDRB.

Sementara itu variabel konsumsi pemerintah daerah $(G)$ dan variabel tenaga kerja memberikan kontribusi yang positif akan tetapi tidak signifikan dampaknya terhadap pertumbuhan ekonomi regional.

\begin{tabular}{|c|c|c|c|}
\hline \multicolumn{4}{|c|}{ Rata-rata pertumbuhan ekonomi tahunan $=4,8 \%$} \\
\hline Sektor Swasta & & Sektor Publik Lokal & \\
\hline Tenaga Kerja & $\begin{array}{l}\text { Penerimaan Pajak dan } \\
\text { Non-pajak }\end{array}$ & $\begin{array}{c}\text { Investasi Pemerintah } \\
\text { Daerah }\end{array}$ & Konsumsi Pemerintah Daerah \\
\hline$-0,08 \%$ & $-7,6 \%$ & $3,9 \%$ & $0,32 \%$ \\
\hline
\end{tabular}

Tabel 2. Dekomposisi Rata-rata Pertumbuhan Ekonomi : 7 Kabupaten/Kota di Eks Karesidenan Surakarta 
Tabel 2 meringkas dekomposisi dari tingkat pertumbuhan ekonomi regional yang terbagi ke dalam sektor swasta dan sektor publik. Secara garis besar hasil estimasi persamaan menunjukkan bahwa ternyata selama periode pengamatan peranan sektor publik lokal mempunyai pengaruh yang signifikan terhadap pertumbuhan ekonomi regional.

\section{SIMPULAN}

Berdasarkan analisis hasil estimasi dan proses perhitungan yang dilakukan diperoleh kesimpulan sebagai berikut:

Pertama, Bahwa selama periode diamati, ternyata secara garis besar hasil estimasi persamaan menunjukkan bahwa ternyata selama periode pengamatan peranan sektor publik lokal mempunyai pengaruh yang signifikan terhadap pertumbuhan ekonomi regional.

Investasi pemerintah daerah $(\mathrm{Ig} / Y)$ menunjukkan kontribusi positif yang signifikan secara statistik dan mengestimasi multiplier dari investasi pemerintah lokal. Hasil ini sejalan dengan penelitian yang dilakukan oleh Kim yang meneliti menganai peranan sektor publik lokal dalam pertumbuhan ekonomi regional di Korea, yaitu bahwa peranan dari sektor publik lokal selama periode 1970-1991 mempunyai pengaruh yang signifikan terhadap pertumbuhan ekonomi di Korea (Kim, 1997:167)

Disisi lain, Koefisien dari penerimaan pemerintah daerah dari pajak dan bukan pajak memberikan efek negaitif yang signifikan terhadap pertumbuhan ekonomi regional. Hasil studi ini sejalan dengan hasil studi dari Helms (1985) dengan menggunakan panel data menemukan bahwa kenaikan dalam pajak lokal dan pajak negara bagian (state) secara signifikan memperlambat pertumbuhan ekonomi ketika penerimaannya digunakan untuk membiayai transfer. Akan tetapi, bagaimanapun ketika penerimaan digunakan untuk membiayai pemeliharaan dan pengembangan jasa-jasa publik, pajak lokal akan mempunyai pengaruh yang menguntungkan terhadap perekonomian regional (Helms, 1985:581).

Demikian juga penemuan Catur Sugiyanto, dkk (1995), meneliti pengaruh pajak terhadap pertumbuhan ekonomi di Indonesia, yang dilakukan dengan cara menurunkan model dengan memasukkan pajak sebagai salah satu variabel yang dipertimbangkan masyarakat untuk menentukan jumlah uang yang beredar. Hasil dari estimasi model yang dipakai ternyata pajak bersifat menghambat pertumbuhan ekonomi. Pajak berhubungan negatif terhadap pertumbuhan ekonomi selama periode pengamatan (1970-1994). Disebutkan bahwa kenaikan pajak yang dipungut oleh pemerintah akan diikuti oleh penurunan kegiatan ekonomi masyarakat (Sugiyanto, 1995:45).

Sementara itu variabel konsumsi pemerintah daerah (G) dan variabel tenaga kerja memberikan kontribusi yang positif akan tetapi tidak signifikan dampaknya terhadap pertumbuhan ekonomi regional. Tidak signifikannya konsumsi pemerintah terhadap pertumbuhan ekonomi kemungkinan bisa disebabkan karena dalam pengeluaran pemerintah untuk konsumsi terjadi inefisiensi yang terjadi dalam penggunaan anggaran sejalan dengan semakin besarnya pos pengeluaran pemerintah.

\section{SARAN DAN IMPLIKASI KEBIJAKAN}

Dengan mempertimbangkan hasil yang diperoleh dari analisis estimasi dari model yang dipakai dalam penelitian ini, ada beberapa implikasi kebijakan dari kesimpulan diatas, diantaranya adalah sebagai berikut:

Pertama, Melihat bahwa ternyata peranan sektor publik lokal selama periode diamati ternyata mempunyai peranan yang berarti dalam pertumbuhan ekonomi regional, maka dengan melihat kapasitas dari sektor publik lokal yang selama ini belum didayagunakan secara optimal (dikarenakan masih banyak dikendalikan dari pusat), maka perlu adanya peningkatan kapasitas dan kinerja dari sektor publik lokal. Dimana hal ini mengimplikasikan perlu adanya otonomi lebih jauh unutk memberdayakan keberadaan sektor publik lokal. dua strategi yang dapat membuat pemerintah lebih kredibel, dan lebih efektif sebagai partner dalam pembangunan negara perlu dipertimbangkan, yaitu: (1) Bagaimana negara Menyesuaikan antara peranan pemerintah dan kapabilitasnya, merupaka elemen pertama dari strategi ini. Kenyataan membuktikan bahwa negara dengan kapabilitas yang lebih tinggi mempunyai efektivitas yang lebih tinggi pula 
dalam memainkan peranannya. (2) Elemen kedua adalah meningkatkan kapabilitas pemerintah (negara) dengan meningkatkan kembali institusi pemerintah. Ini berarti mendesain peraturan dan mengendalikan, untuk mengontrol kegiatan negara yang tidak beraturan dan memberantas korupsi yang sudah berurat akar. Ini berarti bahwa lembaga negara harus lebih kompetitif untuk meningkatkan efisiensinya. Ini berarti pula peningkatan performance lembaga pemerintahan, dan juga membuat negara/pemerintah semakin responsif terhadap kepentingan masyarakat, membawa pemerintah lebih dekat dengan rakyat melalui partisipasi dan desentralisasi. Dalam melaksanakan strategi pertama, kerangka yang bisa dimanfaatkan dengan mempresentasikan klasifikasi fungsi pemerintah sebagai satu kesatuan, dari aktivitas yang tidak boleh dilakukan sampai di bagian mana pemerintah harus memainkan peranannya, yaitu dari fungsi dasar (fungsi minimal), yaitu: ketersediaan barang publik murni, sampai ke fungsi intermediate, dimana pemerintah menyediakan jasa-jasa seperti manajeman eksternalitas, regulasi monopoli, dan terakhir adalah fungsi aktivisnya, yaitu dengan mengkoordinasikan aktivitas sektor swasta. Strategi kedua, meningkatkan kapabilitas yang sudah ada merupakan bagian yang sama pentingnya dari strategi vital ini. Keempat, dalam hal masih terdapat dampak yang negatif dari penerimaan pemerintah daerah dari pajak dan bukan pajak terhadap pertumbuhan ekonomi mengimplikasikan bahwa dampak yang mengakibatkan pajak memperlambat pertumbuhan ekonomi mungkin terjadi ketika penerimaannya hanya digunakan untuk membiayai transfer. Akan tetapi, bagaimanapun ketika penerimaan itu digunakan untuk membiayai pemeliharaan dan pengembangan jasa-jasa publik, pajak daerah akan mempunyai pengaruh yang menguntungkan terhadap perekonomian regional. Disamping itu dari beberapa studi mengenai perpajakan di Indonesia, ternyata sampai dengan saat ini pemungutan pajak di Indonesia belum mencapai tingkat yang optimal bahkan tax effort-nya masih berada jauh dibawah dibandingkan dengan negara-negara berkembang lainnya. Padahal, kenyataan menunjukkan di negara-negara lain, pembiayaan pengeluaran pemerintah sebagian besar diperoleh dari sektor pajak. Sementara untuk kasus Indonesia, dalam pembiayaan pengeluaran pemerintah masih mengandalkan pos pinjaman dari luar negeri - yang notabene sampai saat ini sudah terlampau berat beban hutang luar negerinya dan diambang debt crisis- disamping penggunaan bantuan luar negeri yang tidak efisien sehingga menimbulkan dampak yang negatif terhadap pertumbuhan ekonomi di Indonesia. Melihat fenomena semacam ini, maka perlu dikaji ulang mengenai efek dari bantuan luar negeri dan perlunya dipertimbangkan mengenai peningkatan tax effort melalui program intensifikasi dan ekstensifikasi terhadap obyek pajak sejalan dengan perlunya pembenahan sistem administrasi perpajakan yang selama ini kurang begitu efisien. Dengan demikian diharapkan pos penerimaan dari sektor pajak bisa menggantikan pos pinjaman luar negeri dalam membiayai anggaran pemerintah.

Itulah antara lain beberapa kesimpulan dan implikasi kebijakan yang bisa penulis ajukan sebagai hasil dari analisis empiris mengenai peranan sektor publik lokal terhadap pertumbuhan ekonomi regional di wilayah Surakarta selama periode diamati.

Dibagian terakhir dari tulisan ini penulis ingin menekankan bahwa apa yang diperoleh dari penelitian ini adalah masih merupakan langkah awal dalam penelitian empiris mengenai peranan sektor publik.Tentu saja penelitian ini masih harus dilengkapi dengan banyak penelitian dalam topik yang sama dengan cakupan yang lebih luas dan analisis yang lebih komprehensif serta formulasi model yang lebih canggih.

\section{DAFTAR PUSTAKA}

Akyuwen, Roberto, (2000),"Analisis Pengeluaran Pemerintah", Makalah Seminar Ekonomi Publik, (tidak dipublikasikan).

Ardani,A.(1992), Analysis of Regional Growth and Disparity: The Impact Analysis of The Inpres Project on Indonesian Development (Unpublished), Ph.D Dissertation in City and Regional Planning, University of Pensylvania.

Baltagi, B. H., (1995), Econometric Analysis of Panel Data, John Wiley and Sons, New York. 
Barro,Robert J. (1991), "Economic Growth in A Cross Section of Countries", Quarterly Journal of Economics 105 (2), pp.501-526.

Bartel, Ann P and Harrison, Ann E., (2000), "Ownership versus Environment: Disentangling The Sources of Public Sector Inefficiency", Columbia Business Scholl and NBER.

Estache, Antonia and Rossi, Martin A. (2000), "Comparing the Performance of Publc and Private Water Companies in Asia and Pacific Region What a Stochastic Cost Frontier Shows", working paper.

Carlton, D.W. (1983), "The Location and Employment Choices of New Firms; an Econometric Model with Discrete and Continuous Endogeneous Variables", Review of Economics and Statistics, 65, pp. 440449.

Cullis, John dan Jones, Philip, (1992), Public Finance and Public Choice Analytical Perspectives, McGraw-Hill USA.

Fisher, Ronald C. (1996), State and Local Public Finance, Second Edition, Irwin-US

Greene William H. (2000), Econometric Analysis, Fourth Edition, New Jersey-USA

Grossman, Philip J. and Mavros, Panayiotis and Wassmer, Robert W. (1996), "Public Sector Inefficiency in Large U.S. City", Journal of Economic Literature Classification Codes: H0O, H72, R00, R50.

Helm, L. (1985), " The Effect of State and Local taxes of economic growth: a time series-cross section approach", Review of Economics and Statistics, 67,pp.574-582.

Hotta, (2000), "Pertumbuhan Jepang Pasca Perang dan Pembangunan Pertanahan", Seminar on NRA Environmental Economics.

Hsiao, Cheng, (1995), "Analysis of Panel Data", Econometrics Society Monographs No. 11, Cambridge University Press.

Hyman, David N. (1996), Public Finance, A Contemporary Application of Theory to Policy, Fifth Edition, The Dryden press, USA

Insukindro (1990)," The Monetary Sector in Indonesia: Time Series Property of the Data and Some Issues of Model Spesification", Ekonomi dan Keuangan Indonesia, Vol. 38, No.2

Insukindro (1993), Ekonomi Uang dan Bank: Teori dan Pengalaman di Indonesia, BPFE-UGM, Yogyakarta.

Kim, Sung Tai (1997),"The Role of Local Public Sectors in Regional Economic Growth in Korea", Asian Economic Journal 1997, Vol.11 No.21,pp.155-168.

Kuncoro, Mudrajad (1995), " Desentralisasi Fiskal di Indonesia", dalam Prisma, 4 April.

Makhfatih, Ahmad (1999), "Subsidi: Kasus propinsi di Indonesia 1996/1997", Makalah Ekonomi publik, (tidak dipublikasikan).

Musgrave Richard A. and Musgrave, Peggy B. (1980), Public Finance in Theory and Practice, International Student Edition, Third Edition, Mc Graw Hill International Book company. 
Patnasari, Yenny (1999), "Pengaruh Kebijakan Fiskal terhadap Pertumbuhan Ekonomi di Indonesia", Tesis, pada Program Magister Sains dan Ekonomi FE UGM, (tidak dipublikasikan).

Pindyck, Robert S. and Rubinfeld, Daniel L. (1991), Econometric Model and Economic Forecast, Third Edition, McGraw-Hill Inc, New York.

Rahayu, Siti Aisyah Tri, Sumardi, Yunastiti (2002), Analisis Potensi Keuangan Daerah Menuju Pelaksanaan Otonomi Daerah: Studi Kasus di Kabupaten/Kota se eks Karesidenan Surakarta, Penelitian Dosen Muda, DP3M Dirjen Dikti, (tidak dipublikasikan).

Rama, Martin (2000), "Efficient Public Sector Downsizing" The part of the research project on Public Sector Retrenchment and efficient Compensation Schemes, supported by the Research Committee of the World Bank through grant RPO 679-51.

Ram, R. (1986), "Government Size and Economic Growth: a New Framework and Some Evidence from Crosssection and Time Series Data, American Economic Review, 76, pp. 191-203.

Republik, Indonesia, (2000), "Nota Keuangan dan Anggaran Pendapatan dan Belanja Negara tahun Anggaran 2000".

Sugiyanto, Catur (1995), "Pengaruh Pajak Terhadap Pertumbuhan Ekonomi di Indonesia", Ekonomi dan Keuangan Indonesia, , hal. 29-47.

The World Bank (1997), " The State in Changing World', World Development Report.

Verbeek, Marno (2000), A Guide to Modern Econometrics, John Wiley \& Sons, New York. 